\title{
ECONOMICS
}

\section{DECIPHERING THE HINDU GROWTH EPIC}

\author{
by
}

Peter E Robertson

Business School

The University of Western Australia

DISCUSSION PAPER 10.19 


\title{
DECIPHERING THE HINDU GROWTH EPIC
}

\author{
Peter E. Robertson ${ }^{*}$ \\ The University of Western Australia
}

July 2010

India's investment rate has increased fourfold since 1950 and is now nearly $40 \%$ of GDP. Many studies have suggested that this rising investment rate is the most significant component of India's growth acceleration. I assess these hypotheses using the neoclassical growth model decomposition method. Unlike other methods based on this model, such as Hall and Jones (QJE 1999), the method used in this paper does not rely on the assumption of steady state. I find that the rise in investment rates since the 1970 s explains only $30 \%$ of India's growth over that period. I conclude that, notwithstanding the high investment rates, the main source of India's growth acceleration is the modest upward trend in productivity growth since the 1970s.

JEL: O1

Keywords: Economic Growth, India, Growth Accounting, Investment, Productivity.

\footnotetext{
*Economics, School of Business, University of Western Australia, Perth. Email: peter.robertson@uwa.edu.au
} 


\section{Introduction}

India's rapid economic growth, over the last two decades, is overshadowed by the Chinese economic miracle. Though somewhat slower, India's growth has nevertheless been steady for several decades and is still very dramatic in a global context. Moreover, the fact that it has been achieved within the context of a stable democracy makes India's growth experience a very important model for aspiring developing economies.

Among the explanations for India's success there is a prominent view that the rising investment rate has been a key factor, for example, for example Athukorala and Sen (2002), Bardhan (2006), Basu and Maertens (2007). In particular the investment rate increased fourfold since 1950, and has accelerated particularly quickly since 2000, rising from around $25 \%$ to nearly $40 \%$ of GDP. ${ }^{1}$

Yet the notion that differences in investment rates across time or countries can explain a large fraction of growth sits uncomfortably with the neoclassical growth model and is rejected on that basis by influential studies such as Hall and Jones (1999), Prescott (1998), Klenow and Rodriguez-Clare (1997), Caselli (2005) and Hsieh and Klenow, (2010). They also expressed dissatisfaction with standard growth accounting analyses which fails to take account of the interaction between productivity growth and capital accumulation. Hall and Jones (1999) propose an alternative methodology which relies on the steady-state behaviour of the neoclassical model.

\footnotetext{
${ }^{1}$ The view that the rise in investment rates is a key factor in India's growth is also widely held in the poplar policy debate literature Shome (2006), Mohan (2008), The Economist (2010). One voice of dissent, however, is Bosworth, et al (2007) who lament the lack of capital growth in India's development. They point to India's poor business climate indicators as a potential source of the "modest" capita growth. These conclusions are based largely on growth accounting studies which report, in the words of the authors, a modest contribution from capital. I have discussed these growth accounting results further in a companion paper, Robertson (2010).
} 
The usefulness of the Hall and Jones (1999) decomposition approach has been questioned by Caselli (2005). Moreover, the usefulness of the steady state conditions is likely to be inappropriate for studying transitional growth, as is being experienced by India. To this end this paper describes and applies an alternative method for decomposing the sources of growth in India. It calculates the exact contributions of changes in investment and productivity, according to the neoclassical models allowing for both transitional growth and the endogeneity of capital accumulation.

Section 2 of this paper reviews the Indian growth data and the debate over the role of reforms in India's growth and presents the standard growth accounting results. Section 3 describes the Hall and Jones approach and applies it to India. The main analysis and results are then presented in Section 4, and Section 5 concludes.

\section{Reforms and the Growth Acceleration}

\subsection{The Reform Process}

The basic facts of India's growth are well known. Figure 1 shows India's GDP per capita, $Y / L=y$, since 1950. It also shows the smoothed series using a Hodrick-Prescott (HP) filter. The data is in logs and indexed to $y=1$ in 1950 . The rising growth rate can clearly be seen though the acceleration is gradual, beginning in the late 1970s or early 1980s. Figure 2 shows the same data graphed in terms of annual growth rates rather than levels. It can be seen that the growth rate of GDP per worker accelerates from around $1.5-2 \%$ per year prior to 1970 , after which it accelerates steadily to just over 5\% per year in 2007.

Figure 3 shows gross investment as a fraction of GDP at current market prices from the Reserve Bank of India (RBI). The graph indicates a fairly steady rise in the investment rate and also emphasises the acceleration over the last decade. There is also a slow growth period 
in 1967-1973, after which there is steady growth. A number of authors, including Athukorala and Sen (2004), Sen (2007), Virmani (2004) and Basu and Maertens (2007), have identified this change with the nationalization of banks and the rise of domestic savings, facilitated by policies that required these nationalised banks to extend their branches into rural areas.

The relationship between these changes in the growth and investment rates and the economic reform process has been controversial, and is dubbed the "great growth debate" by Panagaryia (2008). De Long (2003) sparked the debate by pointing out that the apparent acceleration in growth rates preceded the reform era, which began in 1991, by several years. For example in Figure 2, the simple HP trend series indicates an acceleration well before 1991, and possibly as early as 1970. Rodrik (2003) and Rodrik and Subramanian (2004) take this issue further arguing that because this acceleration precedes the extensive reforms of 1990-91, the acceleration in growth was not related to any specific reforms. Rather, they argue, it arose as a consequence of a switch from a socialist political environment to a probusiness one. It was, in their words, the cessation of government hostility to the private sector, which sparked the growth process.

Panagariya (2004, 2008) and Srinivasan (2005) view the Rodrik and Subramanian thesis as a mis-reading of the India's policy regime, showing that, contrary to Rodrik and Subramanian's assertion, there were significant reforms during the 1980s. Panagayria (2008) in particular details many pro-market reforms that had been enacted prior to 1991. These include a delicensing of a large fraction of the manufacturing sector, enhancing its ability to expand, and the removal, or softening, of investment regulations on large firms. There were also trade reforms, including: an expansion of the list of allowable capital and intermediate goods imports; the conversion of import licences to tariffs, and; changes to export licensing arrangements including the formation of export processing zones. Indeed, because of its 
piecemeal nature and focus on easy targets, Panagriaya (2008) denotes this an era of "liberalization by stealth".

Furthermore Panagriaya (2008) notes that rising government spending at this time was fuelled by borrowing rather than taxation, which he argues also stimulated short-run economic growth. With a closed economy and fixed exchange rates, however, the extent to which this fiscal expansion could be funded was limited by the inability to borrow externally.

The major reforms are then marked by the New Industrial Policy of 1990-91, which removed investment licensing, import licensing, public sector monopolies, and introduced automatic approval for foreign direct investment (FDI). According to Panagriaya (2008) and Srinivasan (2005), these reforms had the effect of locking in the higher growth that had been archived through the combination of piecemeal reforms and fiscal deficits during the 1980s.

Recently Sen (2007) has given more weight to the view that significant reforms predated the 1991 reform programme, and were even occurring in the 1970s. He points to the rise in investment since the mid 1970s which was mainly due to the increase in corporate investment in machinery and equipment capital, which increased from below 2\% of GDP in 1979 to above $6 \%$ by 1991 . It then boomed temporarily to above $10 \%$ of GDP after the new Industrial policy was introduced. Sen (2007) argues that financial deepening was a key determinant of this rise in private equipment investment along with complementary investment in infrastructure.

The link with financial deepening is important since Athukorala and Sen (2004), and Basu and Maertens (2007) have emphasised the importance of the expansion of bank branches following the nationalization of commercial banks in 1969, and the formation of the Unit Trust in 1964. Hence this evidence points to specific reforms in the 1960s and early 1970s that may have also had an impact of India's growth. As noted by Sen (2007), there is also 
evidence of a rising growth rate during the 1970s, once allowance is made for the effects of the drought and second oil shock in 1979. As can be seen in Figure 1 the acceleration would appear quite smooth in the absence of the large negative shock in this year.

Thus the emerging view is that reforms beginning as early as 1969 sparked the acceleration in the growth rate. These reforms continued in piecemeal fashion through the 1980s until the more radical new industrial deregulation in the early 1990s locked in higher growth rates by much more widespread de-licensing, removal of investment barriers and external sector reforms.

\subsection{Productivity Growth}

The reforms are generally believed to have raised growth rates through two channels. The first is the impact on investment through regulations affecting banking in the 1960-70s and the removal of direct regulations on investment. The subsequent impact on investment rates was discussed above. The second channel is the direct effect of reforms on economic efficiency, and the adoption of best practice technologies through pro-competitive effects within industries. ${ }^{2}$ These effects are difficult to quantify, but can be measured, albeit imperfectly, by Total Factor Productivity (TFP) growth.

The most common method of calculating TFP is to assume that real output of the economy is described by a Cobb-Douglas production function. Letting $Y_{t}$ denote real output at time $t$ we have $Y_{t}=A_{t} K_{t}{ }^{\alpha} L_{t}^{1-\alpha}$, where $K_{t}$ is capital, $L_{t}$ is labour and $A_{t}$ is an index of productivity measured in units of output, including improvements in labour quality. The usual concept of capital is accumulated investment using the perpetual inventory method,

\footnotetext{
${ }^{2}$ The effects on trade liberalization of the Auto industry is a notable example, where a modern auto industry has replaced a state monopoly under which 1950's technology, in the form of a re-badged Morris Oxford, had persisted into the 1990 s.
} 


$$
K_{t+1}=K_{t}+I_{t}-\delta K_{t}
$$

Where $I$ is investment spending and $\delta$ is the depreciation rate. Letting $y=Y / L$ denote labour per worker, $k=K / L$ denote capital per worker and, output per worker terms is,

$$
y_{t}=A_{t} k_{t}^{\alpha}
$$

and TFP is calculated as $A_{t}=y_{t} / k_{t}^{\alpha}$, which is an index of productivity measured in units of output.

The results of this standard growth accounting decomposition are shown in Table 1 . The variables reported are average growth rates over the period indicated. ${ }^{3}$ Column 1 reports average rates of output growth per capita for India. Column 2 reports the rate of capital accumulation and the "capital contribution" is reported in Column 3. The "capitalcontribution is simply the assumed capital income share, multiplied by the growth rate of capital. The difference between Column 1 and Column 3 is the "Solow-Residual - the growth rate of conventionally measured productivity. The calculations all assume a capital income share of $\alpha=1 / 3$.

For the whole period $1950-51$ to $2007-08$ it can be seen that the growth rate of capital is the same as the growth rate of output, 2.8\%. Because of this the growth accounting decomposition simply assigns $1 / 3$ of growth to capital accumulation and $2 / 3$ to productivity, so that the Solow residual is simply $1.8 \%$. This highlights the insipidness of growth accounting, at least in terms of relating the results to theory or policy implications.

Nevertheless the impact of the acceleration in investment rates from the 1970's can be seen in the growth accounting data also. Relative to the previous two decades, from the 1970s

\footnotetext{
${ }^{3}$ The output and labour data are taken from the Reserve Bank of India (2010) and Bosworth et al (2007). The capital stock data is computed using the RBI gross fixed investment data and with an assumed rate of depreciation of 0.025
} 
onwards the average growth rate of productivity rises marginally but the rate of growth of capital rises from $1.1 \%$ to $3.8 \%$. Over this period productivity growth accounts for 1.9 percentage points of the 3.2 percentage point growth rate of GDP per worker, or $60 \%$ of the growth. Thus the relative contribution of capital in this case is $40 \%$, up from $33 \%$ over the whole period and just $19 \%$ in the period 1950-1970. Thus standard growth accounting suggests that capital accumulation suggests that India's higher growth since the 1970s is, at least partly, explained by higher rates of capital accumulation relative to earlier periods. This at least is consistent with the view that raising investment rates have been important. Nevertheless it does not provide us with an answer to the question we wish to answer, which is, how much extra growth was generated by the rise in the investment rates over a specific fine time period?

\section{Neoclassical Models.}

Thus we have seen that, although the growth accounting results indicate how the growth rate of productivity has changed, they don't tell us how much of the additional growth in this period was due to the increases in investment rates, or how much was due to productivity growth. To answer these questions we need a theory of how capital accumulation and productivity growth are related.

Standard growth models, such as the Solow-Swan model and the Ramsey models, show that policies that affect the investment rate, such as taxes, subsidies and financial sector regulation, will induces changes in income levels and transitional growth rates, but not long run steady state growth rates. Specifically in the Solow-Swan model there is a simple relationship between income and investment,

$$
I_{t}=s Y_{t} \text {. }
$$


The growth rate of the economy converges to a steady state growth rate where per capital income growth is equal to the growth rate of productivity in terms of effective labour units. Increases in the investment rate, $s$, and changes in the level of productivity, $A$, will both raise the steady state income level. In this model it is well known that the ratio of steady state per capita income levels from an initial investment rate $s$, to a new rate $s^{\prime}$, is

$$
y^{\prime} / y=\left(s^{\prime} / s\right)^{\alpha /(1-\alpha)}
$$

For example if $\alpha=1 / 3$, the four-fold increase in the investment rate will produce a doubling of GDP per capita over a full transition. Thus the impact of a percentage change in the investment rate has a much more muted impact in the percentage change in income levels. ${ }^{4}$

However changes in productivity also have an impact on income levels. An increase in productivity from $A$ to $A^{\prime}$ will raise GDP per worker by $y^{\prime} / y=\left(A^{\prime} / A\right)^{1 /(1-\alpha)}$. Thus a given percentage increase in productivity has a magnified effect on per capita incomes. For example, with $\alpha=1 / 3$, a doubling of productivity, $A^{\prime} / A=2$, will induce a three-fold increase in GDP per worker. This magnified effect arises because productivity growth also induces capital accumulation.

This point is well known in the literature and was raised explicitly as a concern about growth accounting by Klenow et al (1997) and Hulten and Srinivasan (1999) among others. In their cross country accounting Hall and Jones (1999) suggest a modified version of this process which relies on the steady state equilibrium of the neoclassical growth model. Hall and Jones' (1999) approach is easiest to see by rewriting the production function with productivity measured in effective labour units

\footnotetext{
${ }^{4}$ The investment equation can be modified to include barriers to investment that reduce the efficiency of converting a given amount of financial investment to physical capital. In this case an expression similar to (4) can be derived for the Ramsey model relating changes in barriers to investment to changes in income levels.
} 


$$
y=k^{\alpha} B^{1-\alpha}
$$

where $B \equiv A^{1 /(1-\alpha)}$, is productivity, but is now expressed in equivalent units of labour rather than units of output. Since the production function is Cobb-Douglas (2) and (5) are equivalent, the only difference being the units in which productivity levels are measured. By dividing both sides of (5) by $y^{\alpha}$, the production function can be rearranged as

$$
y=(k / y)^{\alpha /(1-\alpha)} B
$$

It is well known that in the neoclassical model, on a steady state $k / y$ is constant and both $y$ and $k$ grow at the same rate as technology measured in labour units, $B$. Thus consider an economy that has moved from one steady-state to another as a result of both: (i) changes in the level of productivity, from $B$ to $B^{\prime}$, and; (ii) changes in the investment rate that changes $k / y$ but not $B$. Hall and Jones (1999) use Equation (6) to decompose the changes in income into the productivity term, $B^{\prime} / B$, and the capital deepening term given by changes in the $k / y$ ratio using variance decomposition. They do this by computing the $k / y$ ratios across countries and then inferring the change in $B .^{5}$

Table 2 reports the results of this alternative steady-state based decomposition applied to the Indian data. ${ }^{6}$ Column 1 reports output per worker again for reference. Column 2 reports the average rate of growth in the capital-labour ratio. Column 3 then reports the growth rate of the capital output ratio weighted by $\alpha /(1-\alpha)$, as in (6). The residual is productivity growth measured in effective labour units, $B$, shown in Column 4 .

\footnotetext{
${ }^{5}$ Equivalently one could simply scale up the changes in TFP ratios calculated from standard growth accounting using the relationship $\left(A^{\prime} / A\right)^{1 /(1-\alpha)}=B^{\prime} / B$.

${ }^{6}$ Hall and Jones use a variance decomposition methodology to explain how variations in productivity and capital output ratios explain variations in per capita incomes. Here we simply make pairwise comparisons over points in time. As with the previous growth accounting results ratios are converted to annualised growth rates. Thus for example the growth rate of GDP per worker is calculated as $g_{y}=\left(y^{\prime} / y\right)^{1 / T}-1$.
} 
It can be seen that, according to the Hall and Jones (1999) decomposition, between 19502007 productivity growth as measured by the growth rate of productivity in labour units $B$, explains all of India's growth. Consequently changes in the capital to output ratio explain none of India's growth!

This aberrant conclusion is an immediate implication of the fact that that the capital to output ratio, on average, has been stationary. From (6) if $k / y$ does not change, all growth must be due to changes in $B$. Given that there was a quadrupling of the rate of investment over the period of study, however, it is clearly unreasonable to attribute none of India's growth to capital deepening!

The clumsiness of this method is, therefore, primarily a consequence of the use of the steady state, and hence the implicit assumption that the growth rate of productivity is the same at the start and end dates. In particular, a rise in the growth rate of productivity, not just a change in the level, will cause the capital-output ratio to fall. Hence the rising productivity growth and rising investment rates in India have approximately offset each other so that the capitaloutput ratio has remained constant. But this does not mean, as is suggested by the Hall and Jones type decomposition, that productivity growth was the only source of growth. Growth rates clearly would have been lower if the investment rate had not risen as fast as it did.

Thus, though Hall and Jones's (1999) method may be suitable for some purposes, it should probably not be taken too seriously when applied to periods of time where productivity growth rates are thought to have changed, or across countries where productivity growth rates may differ. ${ }^{7}$

\footnotetext{
${ }^{7}$ Caselli (2005) also expresses reservations about the Hall and Jones (1999) method, pointing out that it mixes up productivity and accumulation responses, since output depends on productivity growth. However one could counter that capital accumulation also depends on productivity growth. His solutio is to resort to the usual growth accounting method treating capital accumulation as independent of productivity.
} 


\section{Decomposing Growth with Simulation Methods}

\subsection{Simulation}

More desirable is a decomposition method that makes use of the insights of the neoclassical model, relating productivity growth to capital accumulation, but without imposing the assumption of a steady state or constant growth rate of productivity. To do this is remarkably simple using a simulation method. We begin with the standard growth accounting data, including capital stocks calculated using the perpetual inventory method, given by (1). This gives us the standard growth accounting data as discussed above: investment flows, $I_{t}$, labour flows $L_{t}$, capital stocks, $K_{t}$, real output flows, $Y_{t}$, and also an assumed production function as in (2), with given values of the factor shares, $\alpha$. Standard growth accounting recovers the values of $A_{t}$.

To this I add the neoclassical relationship between factor accumulation and incomes as in (3), allowing for the fact that in practice the investment rate, $s$, varies over time, $I_{t}=s_{t} Y_{t}$. The actual values of $s_{t}$ can then be recovered from gross investment and GDP data as $s_{t}=I_{t} / Y_{t}$.

Thus we have a series of values for $K_{t}, Y_{t}, A_{t}, s_{t}$ and $L_{t}$, which is the data required to calibrate the Solow-Swan growth model. It is a three equation recursive dynamic system (1), (2) and (3). Consistent with that model we treat $K_{t}, Y_{t}$, as endogenous variables and $A_{t}, s_{t}$ and $L_{t}$ as exogenous variables. Observations on initial values of $K_{t}, Y_{t}, A_{t}, s_{t}$ and $L_{t}$, determine $K_{t+1}$ using equation (1). Given the production function, the exogenous values of $A_{t+1}$ and $L_{t+1}$ determine $Y_{t+1}$. In this way, the actual data can be reconstructed exactly. 
Moreover, every change in income can be decomposed exactly into a change in inputs, the investment rate or a change in productivity. ${ }^{8}$

For any experiment we continue to treat $A_{t}, s_{t}$ and $L_{t}$ as exogenous variables and $K_{t}, Y_{t}$, as endogenous variables. The effects of productivity on growth can be determined by considering an alternative series for productivity growth, which we denote $A_{t}^{\prime}$. Likewise we can calculate the impact on $K_{t}$, and $Y_{t}$, of a counterfactual series for the investment rate, $s_{t}^{\prime}$, holding $A_{t}$ and $L_{t}$ constant. In this way we can decompose the influences of these alternative factors on growth, allowing for endogenous capital accumulation responses over transitions. No steady state assumptions are necessary.

\subsection{Results}

Following Sen (2007) we take 1970 as the date where India's current acceleration begins. We therefore assess the role of the effect of the acceleration in investment rates on India's growth, and the effect of the acceleration in productivity growth, since 1970-71. To quantify the impact of the rise in investment rates we consider the comparative static experiment: what would growth have been had the investment rate remained constant at its 1970 level of $15 \%$ ?

Choosing a counterfactual for productivity growth is not quite as straightforward as there is substantial variation in the productivity series. As shown in Figure 4, the trend rate of conventionally measured Solow-Residual fell from 1950 to the 1970s, when it reached a minimum of just under 0.8 percent. Since then the trend has accelerated. In what follows I quantify the role of this productivity growth acceleration from 1970. Thus, in the

\footnotetext{
${ }^{8}$ Changes in depreciation rates could also be accommodated using official capital consumption data. In the interest of simplicity I abstract from this factor. A similar method is was also employed to look at the East Asian Miracle, by Robertson (2000)
} 
counterfactual base we hold productivity growth rate fixed at its 1970 level of $0.8 \%$, $A_{t+1} / A_{t}=1.008$

The results of these experiments, along with the actual path of GDP per capita since 1969-70, are shown in Figure 5. The path denoted Simulation 1, (S1) is a counterfactual path generated by holding both the investment rate at $15 \%$, and the productivity growth rate at $0.8 \%$. The path denoted S2 is the path generated by allowing the investment rate to rise according to the actual data, but holding the productivity growth rate at 0.8 per cent per year. In S3 productivity growth rates take on their actual values, and the investment rate is held constant at $15 \%$.

Comparing the ratio of GDP per capita in S2 relative to GDP per capita in S1 then gives the impact of the rise in investment rates on GDP per capita. Likewise comparing the ratio of GDP per capita in $\mathrm{S} 3$ relative to $\mathrm{S} 1$ gives the impact of the acceleration in productivity growth. By design when both of these are combined together we arrive at exactly the historical growth path shown. In this way we can obtain a sensible decomposition of the contribution of these two factors to India's growth acceleration.

The graph shows the substantial difference of the impact of these two sources of growth. The average growth rate in $\mathrm{S} 2$ is approximately half a percentage point per year higher that the reference growth path $\mathrm{S} 1$. However the path generated by the rising productivity growth rates, $\mathrm{S} 3$, is more than double this, at 1.2 percentage points higher.

Further details of these calculations are given in Table 2. Column 1 gives the ratio of GDP per worker in 2007-08 to actual 1970-71 GDP per worker. Thus there was a three-fold increase over this period. Under S1 there is only a 1.6 fold increase in GDP per capita, while under S2 and S3 the increase are approximately 1.97 fold and 2.56 fold respectively. Column 2 reports the implied average growth rates over the 37 year period. Column 3 then reports the 
difference in these average growth rates relative to $\mathrm{S} 1$. Thus it shows that $\mathrm{S} 2$, the rising investment rate, increases growth rates by half a percent per year. In contrast the productivity growth experiment (S3) adds approximately $1.4 \%$ points of GDP per capita growth. Finally Column 4 then reports these growth rates as a fraction of the actual growth gap between the actual experience and the base simulation in S1, which gives the results reported above.

Thus, despite the dramatic rise in investment rates, this explains only $30 \%$ of the differences in growth rates between $\mathrm{S} 1$ and the actual growth in the standard neoclassical growth model. In contrast the rise in productivity growth since 1970 explains $68 \%$ of the growth. The $2 \%$ remainder is due to interaction between these two components.

It is evident that the productivity acceleration has been much more important than the acceleration in investment rates. This is perhaps surprising since the acceleration in investment rates has been much more dramatic, and certainly received considerable attention in the literature. The results of course reflect the mechanics of the neoclassical model, where, within the empirically valid range of capital income shares, the diminishing returns to capital reduces the impact of accumulation on income levels.

\subsection{Discussion}

It is interesting then to compare these results with the two growth accounting methods reported above. For the post 1970 period the standard growth accounting method attributed 1.26 percentage points of growth (1/3 of 3.8 percentage points) to capital accumulation and 1.9 percentage points to productivity. The division was thus approximately $60 \%$ productivity and $40 \%$ factor accumulation. On the other hand the Hall and Jones' (1999) method attributes practically all the growth (99\%) to productivity and only $1 \%$ to accumulation.

The results derived using the simulation model take account of the endogeneity of investment, as is the aim of the Hall and Jones (1999) method, but give very different results. 
Specifically the Hall and Jones (1999) method dramatically overstates the impact of productivity in this case, because, in India, it does not account for the impact of an acceleration in productivity growth on reducing the capital-output ratio.

Moreover these simulations answer specific questions about the partial dynamic impacts of observed changes in the investment rate and productivity growth rates. In contrast, standard growth accounting methods fall short of informing us on these types of questions.

\subsection{Sensitivity}

A potential important consideration is the economic impact of changes in the income shares of capital and labour. As the capital income share, $\alpha$, increases, changes in the investment rate will have larger impact on GDP. In the limit, as $\alpha$ approaches unity the model approaches an "AK model, and increases in investment rates will have permanent effects on the growth rate.

Tables A1 and A2 in the appendix show that for moderate changes in the capital income share, there are also important effects. With $\alpha=0.4$, the impact of the investment rate increase is substantially larger, though still smaller than the impact of productivity growth, with the division approximately $41 \%$ investment and $57 \%$ productivity. With $\alpha=0.3$, however we have $25 \%$ due to investment and $73 \%$ due to productivity. Thus to reverse the conclusion that the investment rate increases have been a secondary source of growth we would need to assume a capital income share substantially greater than 0.4 . This of course reflects the basic properties of the neoclassical growth model (see for example Caselli 2005). ${ }^{9}$

\footnotetext{
${ }^{9}$ A second potential consideration is the elasticity of substitution, which is equal to unity in a Cobb-Douglas production function. Simulations with a CES production function, however, show very little change in the results across a wide range of potential values for the elasticity of substitution.
} 


\subsection{India's Latest Investment Boom}

One feature of the rise in investment rates since the 1970s is that it has been fairly gradual, though steady until the new millennium. As can be seen from Figure 3, India's investment rate rise has been much more spectacular since 2000-01, rising from 25 to $37 \%$. Commentators such as Basu and Maertens (2007), Mohan (2008), and Basu (2008) have cited this boom as a likely important source of India's strong growth in the new Millennium. As we have seen however, productivity growth has also been strong particularly since 2003 .

Suppose then we consider a counterfactual growth path where the investment rate from 2000 onwards is held constant at the 2000 level of $25 \%$ of GDP, rather than accelerating up to $37 \%$ of GDP. Figure 5 shows the resulting growth path. It can be seen that holding investment fixed at $25 \%$ has very little impact on the path of per capita incomes. Over this period actual incomes increased by a factor of 1.42 and under the counterfactual it increases by a factor of 1.35. This means that the contribution of investment has been to raise incomes by a factor of $1.42 / 1.32=1.05$. Converting these ratios to growth rates, over the eight year period, gives a growth rate in the counterfactual of $3.8 \%$ per annum, relative to the actual growth rates of $4.5 \%$ per annum. Thus the dramatic increase in investment only accounts for an additional 0.7 percentage points of growth. Thus the contribution of investment over this sub period is almost the same as the contribution over the whole period 1970-2007. ${ }^{10}$

Note however that if the investment rate remains at this higher level into the future, then the longer run accumulation effects will be more substantial. Using (2), the ratio of incomes from the increase in investment rates from $25 \%$ to $37 \%$ is approximately a $(37 / 25)^{1 / 2}=1.22$ fold increase in incomes. Clearly then, this factor will only be a minor determinant of India's

\footnotetext{
${ }^{10}$ With $\alpha=0.4$ the contribution of investment acceleration from $25-27 \%$ rises to 7.7 percentage points, and for $\alpha=0.3$ it falls to 0.65 percentage pints.
} 
growth in the near future, if the current rate of productivity growth, of around 4-5\% per year is also sustained.

\section{Conclusion}

The central question of this paper has been to identify the main sources of India's growth acceleration since the 1970s. But without a clear model of the relationships between the growth data, it is difficult to glean any meaning or policy insights. ${ }^{11}$ Fortunately the neoclassical growth model gives us a potential "Rosetta Stone" with which to decipher India's growth data. Standard growth accounting methods, however, do not fully incorporate the interdependence between productivity and economic growth which is the hallmark of that model. Hence, as pointed out by Hall and Jones (1999) among others, growth accounting overstates the contribution of capital to growth and understates the contribution of productivity.

This paper describes a technique use the neoclassical growth model to quantify the interaction between productivity growth and capital accumulation, allowing for the transitional dynamics. This allows us to derive quantitative measures of the impact of the rise in India's investment rates, thus clarifying a key point of contention in India's "great growth debate."

Because the method here allows for the effect of productivity growth on capital accumulation, the results give more emphasis to the benefits of higher productivity growth than traditional growth accounting does. Thus the additional growth from the acceleration in productivity growth is shown to be greater than just its direct impact, due to its impact of capital accumulation. 
Nevertheless the results are much more sensible than the Hall and Jones (1999) decomposition which attributes practically none of India's growth to investment, despite a quadrupling of the investment rate. Thus I find that investment has indeed played an important, but secondary, role in India's growth acceleration. The actual increase in productivity growth accounts for $68 \%$ of India's post 1970 s growth and the rise in the investment rate accounts for $30 \%$. Thus the upward productivity growth trend has been more than twice as important as the doubling of the investment rate. ${ }^{12}$

A similar conclusion applies for the post 2000 era, where a dramatic rise in investment from $25 \%$ to $37 \%$ of GDP, only adds about 0.7 percentage points of growth to the $4.5 \%$ annual growth rate over this period.

The emphasis on productivity growth for India's success underscores the key role of the reform process. Indeed many economic reforms will affect both investment rates and productivity growth, such as the de-licensing of domestic and foreign investment, removal of restrictions on firm size, increasing openness, and de-licensing of FDI restrictions. These policies facilitate investment but also potentially facilitate investment in new capital goods. In contrast, mandated savings polices and investment based tax concessions - which both effectively reduce the return to capital - may well have the effect of stimulating capital deepening without inducing productivity growth.

\footnotetext{
${ }^{12}$ Alternatively it might be argued that the increase in the investment rate is of primary importance due to its potential impact on productivity - i.e. endogenous growth effects which go beyond the simple neoclassical model used here. For example Athukorala and Sen (2002) find, using a very different model, that reforms factors, such as increased openness in India, increased the impact of investment on growth rates.
} 


\section{References}

Athukorala, Prema-Chandra and Kunal Sen. (2002) Saving, Investment, and Growth in India, Oxford University Press.

Athukorala, Prema-Chandra and Kunal Sen. (2004) "The Determinants of Private Saving in India” World Development 32, 3, 491-503.

Bardhan, P. (2006) “Awakening Giants, Feet of Clay: A Comparative Assessment of the Rise of China and India”, Journal of South Asian Development, 1(1): 1-17.

Basu, Kaushik and Annemie Maertens. (2007) “The Pattern and Causes of Economic Growth in India" Oxford Review of Economic Policy, 23(2): 143-167.

Basu, Kaushik. (2008) “The Enigma of India's Arrival: A Review of Arvind Virmani's Propelling India: From Socialist Stagnation to Global Power", Journal of Economic Literature, 46(2): 396-406.

Basu, Kaushik. (2009) "Asian Century: A Comparative Analysis of Growth in China, India and other Asian Economies", Bureau for Research and Economic Analysis of Development, Working Paper No. 209.

Bosworth, Barry, Susan M. Collins and Arvind Virmani (2007), Sources of Growth in the Indian Economy, NBER Working Paper 12901.

Caselli, Francesco (2005) "Accounting for Cross-Country Income Differences", chapter 9 in Aghion, P and S. Durlauf, Handbook of Economic Growth, North Holland, New York.

DeLong, J. B. (2003) "India since Independence: An Analytic Growth Narrative" in Rodrik (ed) In search of Prosperity: Analytical Narratives of Economic Growth, MIT Press.

DeLong, J. B. and L. H. Summers. (1991) "Equipment Investment and Economic Growth", Quarterly Journal of Economics, 106, (2): 455-502.

Hall, Robert E. and Charles I. Jones "Why Do Some Countries Produce So Much More Output per Worker Than Others?” The Quarterly Journal Of Economics, 14-1, 83-116.

Hulten, Charels and Sylaja Srinivasan. "Indian Manufacturing Industry: Elephant or Tiger? New Evidence on The Asian Miracle”, NBER Working Paper, 7441.

Hsieh, Chang-Tai and Peter J. Klenow. (2010) "Development Accounting", American Economic Journal: Macroeconomics 2,1, 207-223. 
Hodrick, Robert, and Edward C. Prescott. (1997) "Postwar U.S. Business Cycles: An Empirical Investigation," Journal of Money, Credit, and Banking, 29, 1 1-16.

Klenow, Peter J., and Andres Rodriguez-Clare. (1997) “The Neoclassical Revival in Growth Economics: Has It Gone Too Far?” NBER Macroeconomics Annual 1997. MIT Press, pp. 73-103.

Mohan, Rakesh. (2008) “A Story of Sustained Savings and Investment”, Economic \& Political Weekly, 33(19): 61-72.

Panagariya, A. (2004) "Growth and Reforms during 1980s and 1990s", Economic and Political Weekly, 39(25): 2581-2594.

Panagariya, A. (2008) “India: The Emerging Giant”, Oxford University Press.

Prescott, E. C. (1998) "Needed: A Theory of Total Factor Productivity", International Economic Review, 39, 525-551

Rao R.P.N, N. Yadav, M.N. Vahia, H. Joglekar, R. Adhikari and I. Mahadevan (2009). "Entropic Evidence for Linguistic Structure in the Indus Script" Science, 324, 29.

Robertson, Peter E. (2000), "Diminished returns? Investment and the East Asia's Miracle", Economic Record, 76, (235): 343-354.

Robertson, Peter E. (2010), "Investment Led Growth in India: Hindu Fact or Mythology", UWA Business School, Economics Discussion Paper 10.08.

Rodrik, D. (2003) "Institutions, Integration and Geography: In Search of the Deep Determinants of Economic Growth" in Rodrik (ed) In search of Prosperity: Analytical Narratives of Economic Growth, MIT Press.

Rodrik, D. and A. Subramanian (2004), "From Hindu Growth to Productivity Surge: The Myth of the Indian Growth Transition", IMF Staff Papers, 52(2).

Reserve Bank of India, (2010) Handbook of Statistics on the Indian Economy.

Sen, Kunal. (2007) "Why did the Elephant Start to Trot? India's Growth Acceleration Reexamined", Economic and Political Weekly, 42, (43): 37- 47.

The Economist (2010) "Economics Focus: Invested interests" 21 January. 
Shome, Parthasarathi (2006) "At the Threshold of 10 Per Cent Economic Growth?" Economic and Political Weekly, 41(11): 940-943.

Srinivasan, T.N. (2005) "Comments on 'From Hindu Growth to Productivity Surge': The Mystery of the Indian Growth Transition”, IMF Staff Papers, 52(2).

Virmani, A. (2004) “Indian's Economic Growth: From Socialist Rate of Growth to Bharatiya Rate of Growth", Indian Council for Research on International Economic Relations, Working Paper No. 122 
Table 1: Growth Accounting Results $(\alpha=1 / 3)$

\begin{tabular}{|ccccccc|}
\hline & (i) & (ii) & (iii) & (iv) & (v) & (vi) \\
& Output & Labour & $\begin{array}{c}\text { Output per } \\
\text { worker, } y\end{array}$ & $\begin{array}{c}\text { Capital per } \\
\text { worker, } k\end{array}$ & $\begin{array}{c}\text { Capital } \\
\text { contribution }\end{array}$ & $\begin{array}{c}\text { Productivity } \\
\text { growth }\end{array}$ \\
\hline $1950-2007$ & 4.8 & 2.0 & 2.8 & 2.8 & 0.9 & 1.8 \\
$1950-1970$ & 3.8 & 1.7 & 2.0 & 1.1 & 0.4 & 1.7 \\
$1970-2007$ & 5.3 & 2.1 & 3.2 & 3.8 & 1.3 & 1.9 \\
$2000-2007$ & 7.6 & 2.7 & 4.8 & 4.9 & 1.6 & 3.2 \\
\hline
\end{tabular}

Notes: All numbers are average annualised growth rates, calculated as averages using a discrete time formula. In a continuous time approximation, column (vi) equals column (iii) minus column (v). Column (v) equals column (iv) multiplied by $1 / 3$. 
Table 2: Steady State Decomposition based on Hall and Jones $(\alpha=1 / 3)$

\begin{tabular}{|ccccc|}
\hline (i) & $\begin{array}{c}\text { (ii) } \\
\text { Output per } \\
\text { worker, } y\end{array}$ & $\begin{array}{c}\text { Capital output } \\
\text { ratio, } k / y\end{array}$ & $\begin{array}{c}\text { (iii) } \\
\text { Investment rate } \\
\text { contribution } \\
(k / y)^{\alpha /(1-\alpha)}\end{array}$ & $\begin{array}{c}\text { Productivity in } \\
\text { effective labour } \\
\text { units, } B\end{array}$ \\
\hline $1950-2007$ & 2.8 & 0.06 & 0.03 & 2.7 \\
$1950-1970$ & 2.0 & -0.91 & -0.46 & 2.5 \\
$1970-2007$ & 3.2 & 0.59 & 0.29 & 2.9 \\
$2000-2007$ & 4.8 & 0.03 & 0.01 & 4.8 \\
\hline
\end{tabular}

Notes: By the standard growth accounting equation, column (ii) equals column (i) minus one third of the value in column (ii). The values of productivity growth in effective labour units, column (v) equal the difference between column (i) and column (iv). As discussed in the text they also equal the values productivity growth in output units, (iii), multiplied by $3 / 2$. 
Table 3: Growth Simulation Results $\alpha=1 / 3$

\begin{tabular}{|c|c|c|c|c|}
\hline & $\frac{y_{2008}}{y_{1970}}$ & $\begin{array}{c}\text { Average } \\
\text { Growth } \\
\text { Rate } \%\end{array}$ & $\begin{array}{c}\text { Additional } \\
\text { Growth } \\
\text { (actual- } \\
\text { S1) }\end{array}$ & $\begin{array}{c}\text { Relative } \\
\text { Contrib. } \\
\%\end{array}$ \\
\hline Const Productivity and Investment (S1) & 1.60 & 1.28 & 0.0 & 0.0 \\
\hline Actual Investment Growth \&Const. Productivity) (S2) & 1.97 & 1.86 & 0.57 & 30.2 \\
\hline Actual Productivity Growth \& Const. Investment (S3) & 2.56 & 2.57 & 1.29 & 68.2 \\
\hline Actual Growth 1970-01-2006-07 & 3.18 & 3.18 & 1.89 & 100.0 \\
\hline
\end{tabular}




\section{Appendix Tables}

Table A1: Growth Simulation Results $\alpha=0.4$

\begin{tabular}{|lcccc|}
\hline & $\begin{array}{l}y_{2008} \\
y_{1970}\end{array}$ & $\begin{array}{c}\text { Average } \\
\text { Growth } \\
\text { Rate } \%\end{array}$ & $\begin{array}{c}\text { Additional } \\
\text { Growth } \\
\text { (actual- } \\
\text { S1) }\end{array}$ & $\begin{array}{c}\text { Relative } \\
\text { Contrib. } \\
\%\end{array}$ \\
Const Productivity and Investment (S1) & 1.70 & 1.44 & & 40.5 \\
Actual Investment Growth \&Const. Productivity) (S2) & 2.19 & 2.14 & 0.70 & 56.7 \\
Actual Productivity Growth \& Const. Investment (S3) & 2.42 & 2.42 & 0.99 & 1.74 \\
Actual Growth 1970-01-2006-07 & 3.18 & 3.18 & 1.74 & 100.0 \\
\hline
\end{tabular}


Table A2: Growth Simulation Results $\alpha=0.3$

\begin{tabular}{|lcccc|}
\hline & $\begin{array}{l}y_{2008} \\
y_{1970}\end{array}$ & $\begin{array}{c}\text { Average } \\
\text { Growth } \\
\text { Rate } \%\end{array}$ & $\begin{array}{c}\text { Additional } \\
\text { Growth } \\
\text { (actual- } \\
\text { S1) }\end{array}$ & $\begin{array}{c}\text { Relative } \\
\text { Contrib. } \\
\%\end{array}$ \\
\hline Const Productivity and Investment (S1) & 1.58 & 1.24 & & 25.0 \\
Actual Investment Growth \&Const. Productivity) (S2) & 1.88 & 1.72 & 0.48 & 72.6 \\
Actual Productivity Growth \& Const. Investment (S3) & 2.63 & 2.64 & 1.40 & 1.90 .0 \\
Actual Growth 1970-01-2006-07 & 3.18 & 3.18 & 1.93 & 100 \\
\hline
\end{tabular}


Figure 1: Log GDP per Worker

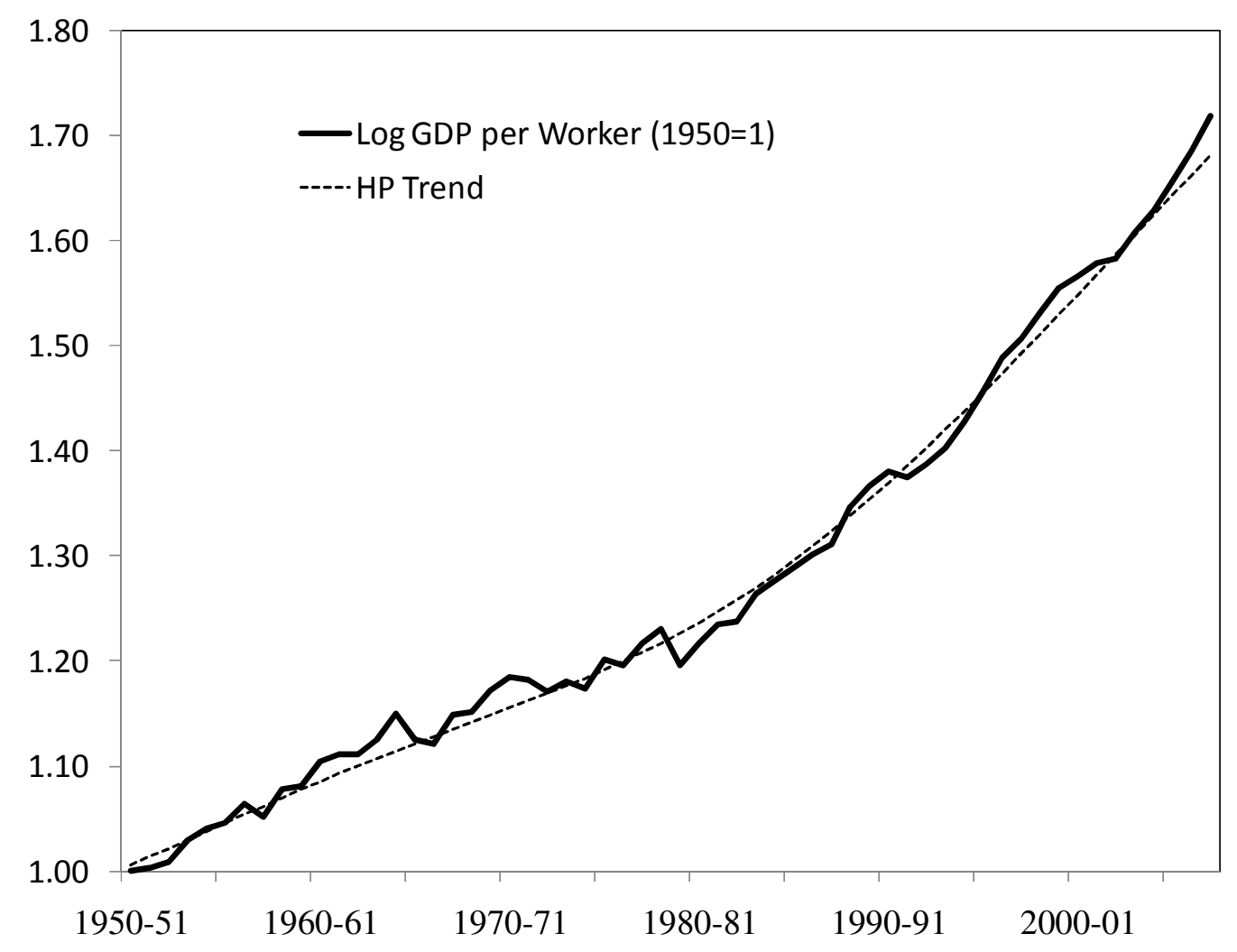


Figure 2: Growth Rate of GDP per Worker

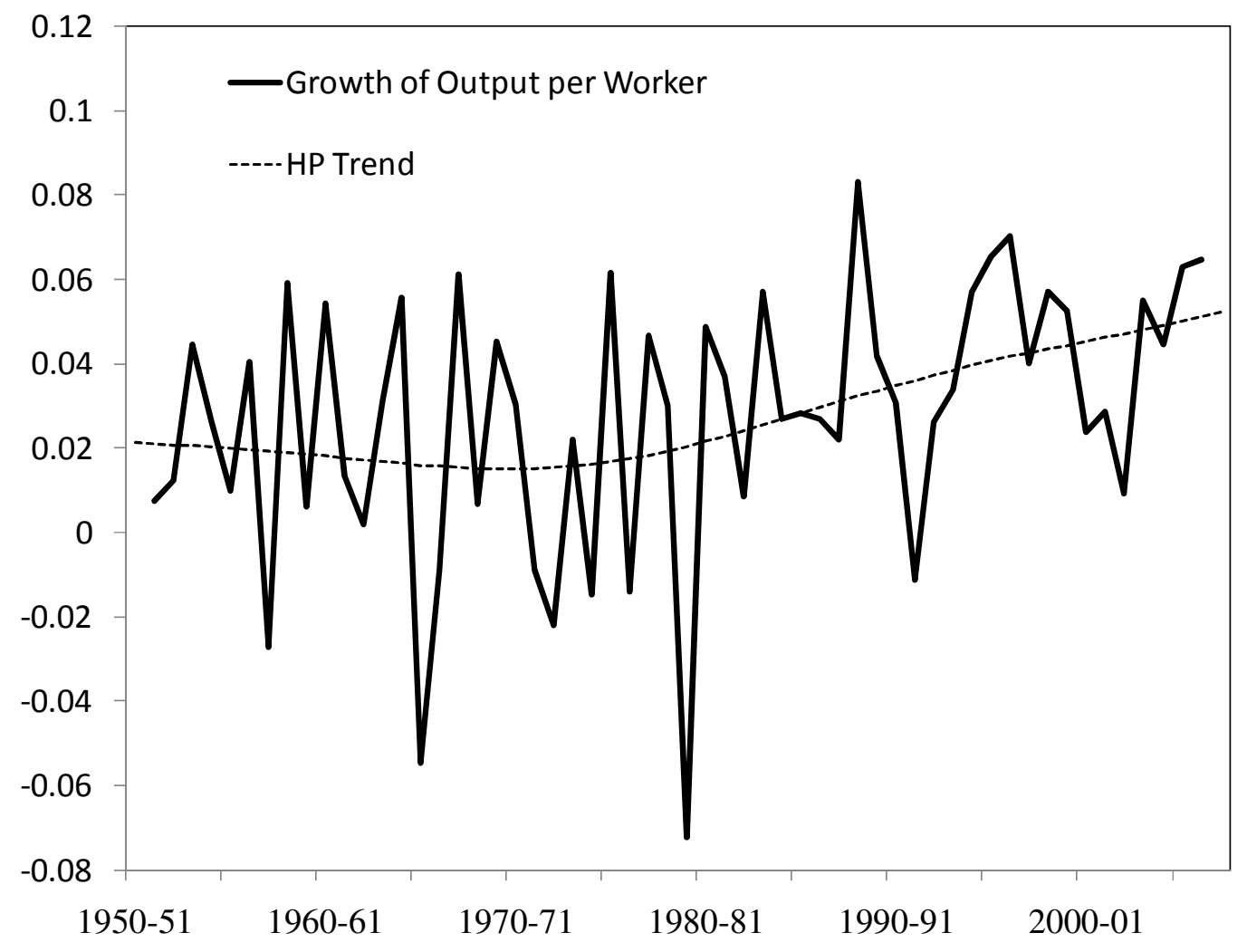


Figure 3: Investment and Savings Rates

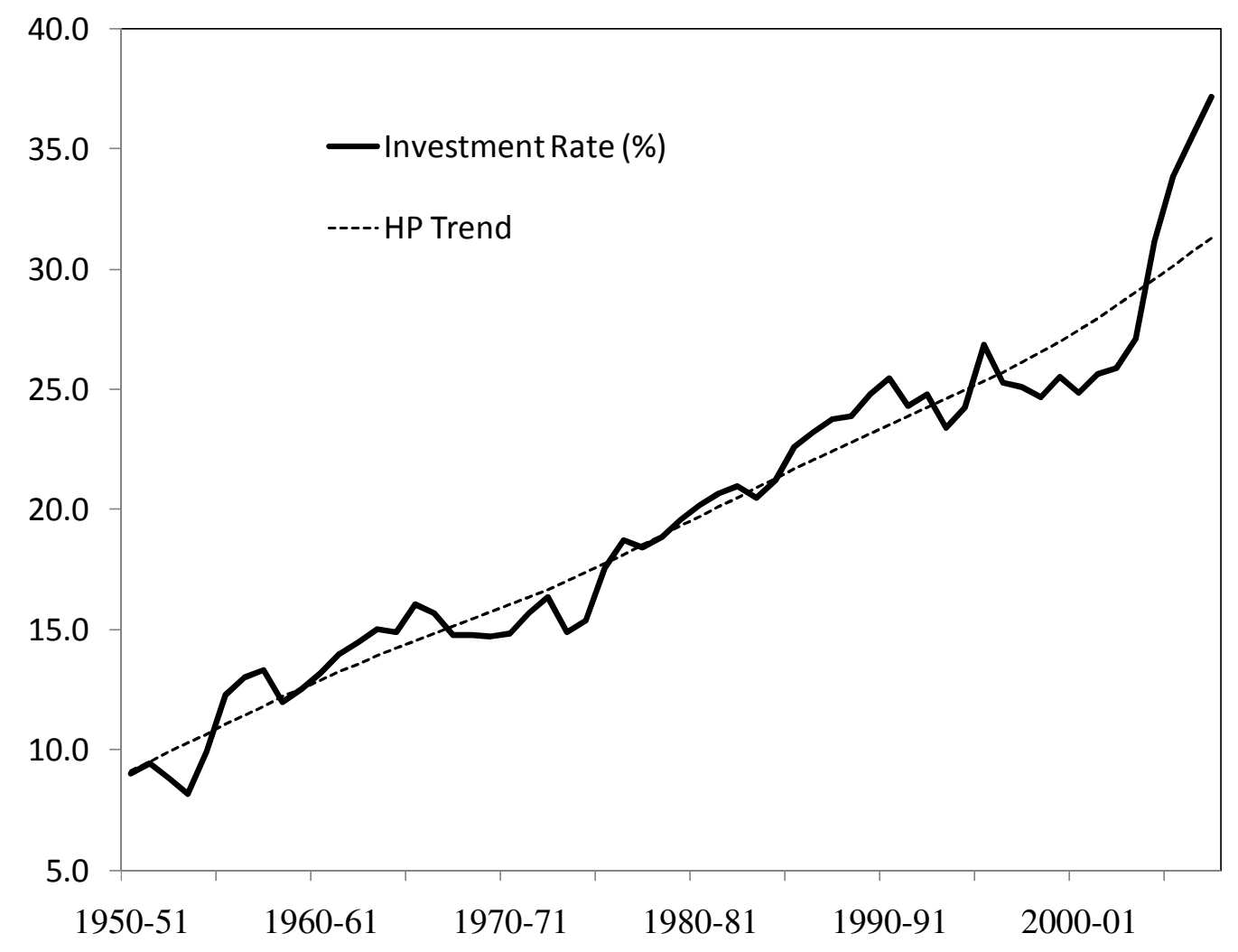


Figure 4: Growth Rate of TFP

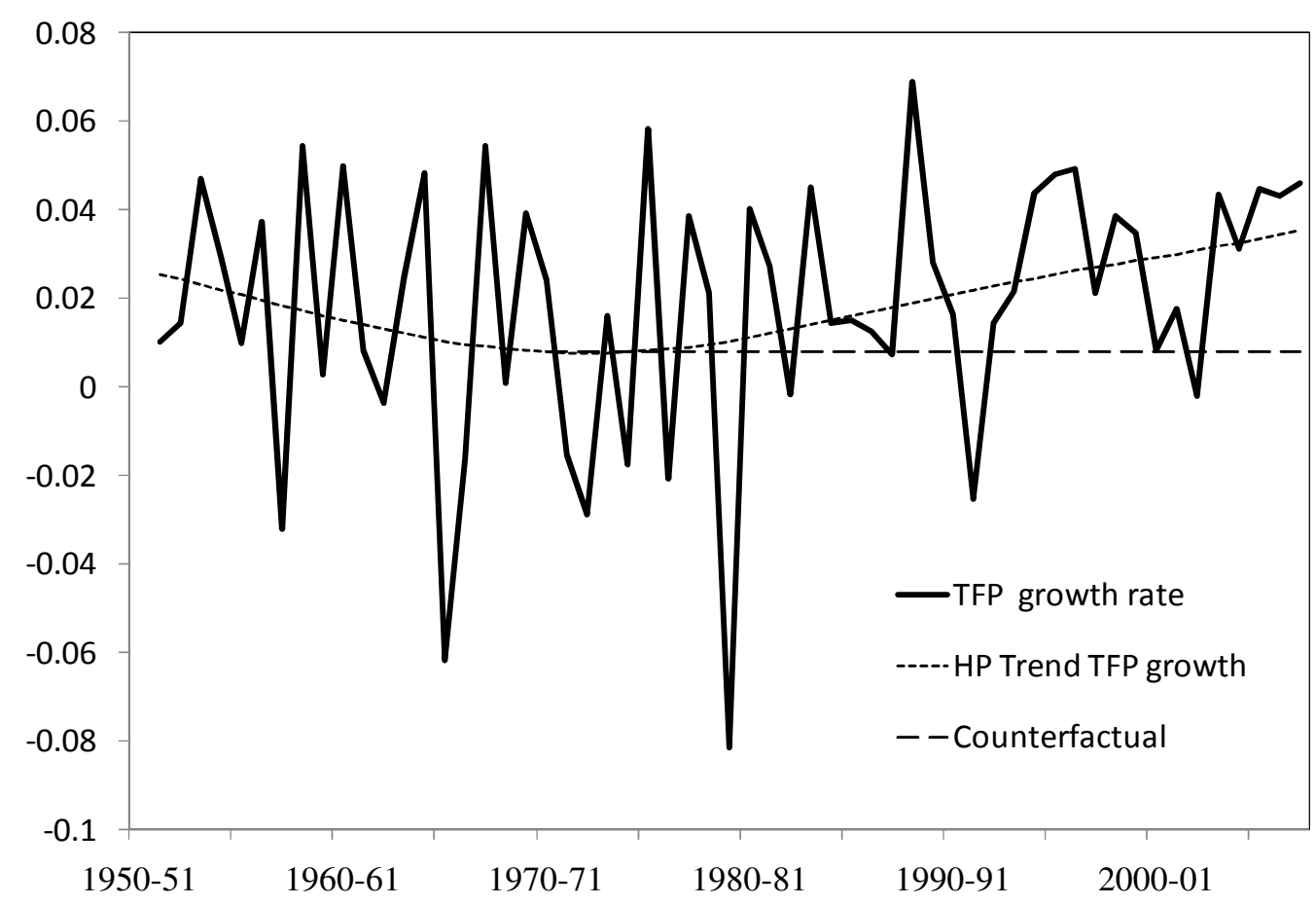




\section{Figure 5: Counterfactual Simulations (Log GDP per worker, 1970-01=1))}

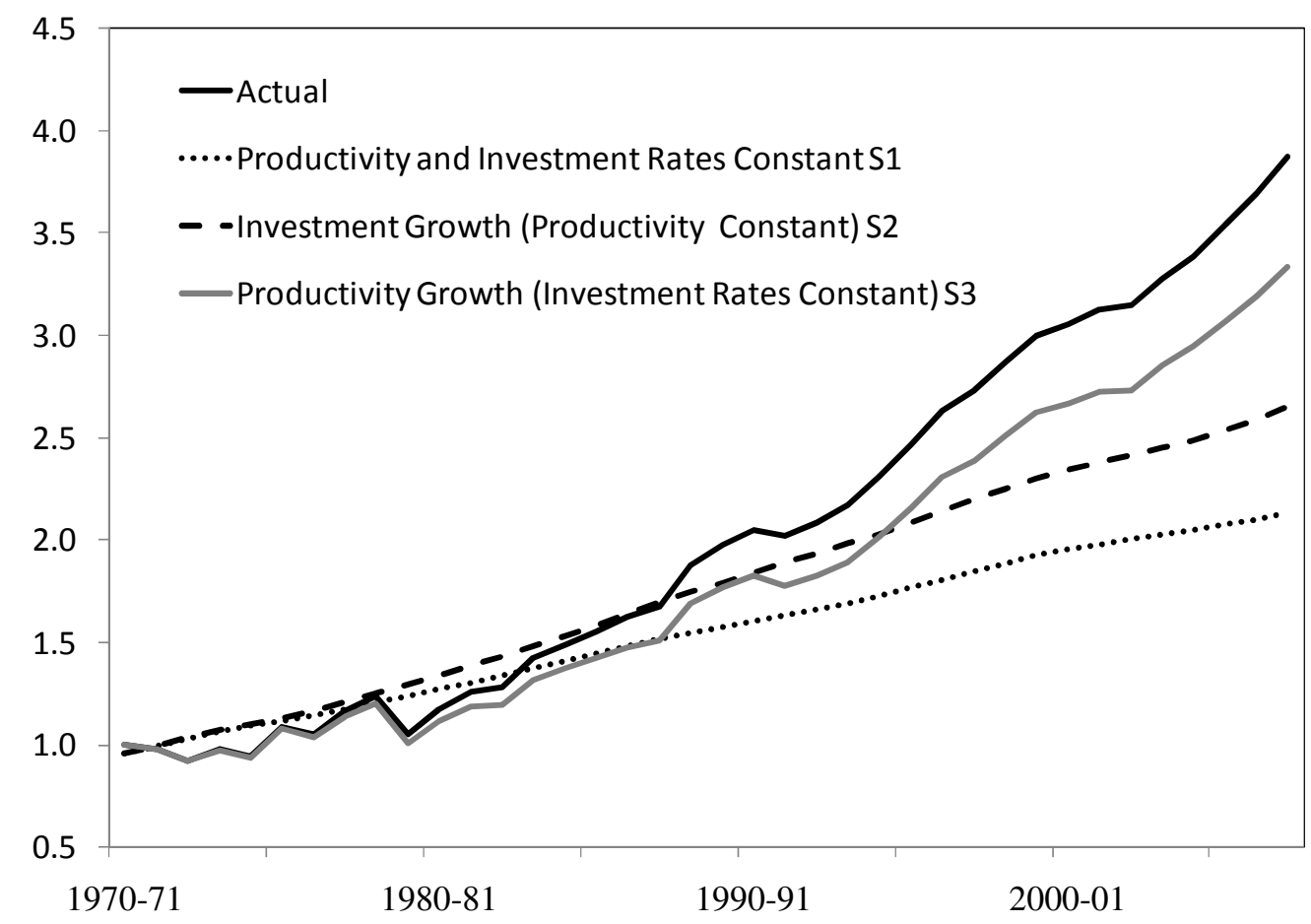


Figure 6: Counterfactual Simulations with $s=0.25$.

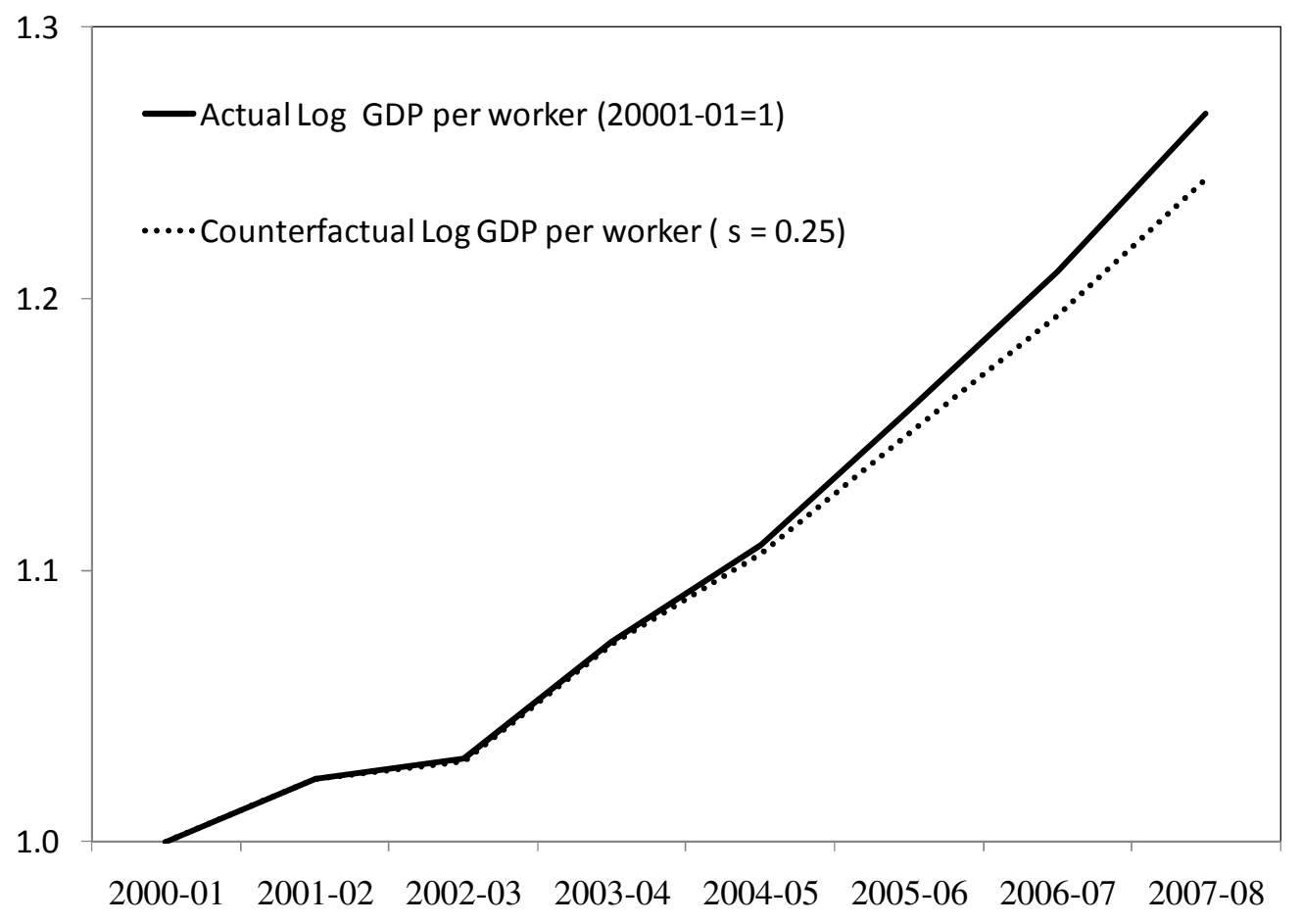




\section{Appendix for the Referee}

The text makes use of the neoclassical growth model. Though this model is well known, for completeness this appendix derives the expressions used in the paper.

Suppose we assume a Cobb-Douglas production function where per capita output, $y$, is given as a function of per capita capital stock, $k$,

$$
y=k^{\alpha} B^{1-\alpha} .
$$

It is well known that the steady state equilibrium condition for the Solow-Swan model, in discrete time, is

$$
\frac{y}{k}=\frac{(1+n)(1+g)-(1-\delta)}{s}
$$

where $1+n$ is the annual increase in labour inputs, $1+g$ denotes the annual increase in productivity, $B, \delta$ denotes the depreciation rate on capital and $s$ is the investment rate.

The model assumes $s, n, g, \delta$ are constant, at least for the purpose of pinning down a steady state.

To find the steady state value of per capita income, $y$, both sides of (A1) are divided by $y^{\alpha}$, which gives

$$
y=(k / y)^{\alpha /(1-\alpha)} B .
$$

The equilibrium value of income per capita is obtained by substituting (A2) into (A3), which gives

$$
y^{*}=(s / \chi)^{\alpha /(1-\alpha)} B
$$

where $\chi=(1+n)(1+g)-(1-\delta)$. From this we obtain the basic equilibrium result for the

model. Since s and c are constant, per capita income $y$ grows at the same rate as productivity, $B$, which is given by $1+g$.

Hence an economy that moves from an initial steady state to a new steady state due to a change in the investment rate from $s$ to $s^{\prime}$, will have an increase in per capita income of

$$
y^{\prime} / y=\left(s^{\prime} / s\right)^{\alpha /(1-\alpha)}
$$


Likewise an economy that experiences a productivity change from $B$ to $B^{\prime}$, but no change in any other variable will experience a proportional increase in per capita income growth,

$$
y^{\prime} / y=B^{\prime} / B
$$




\begin{tabular}{|c|c|c|}
\hline \multicolumn{3}{|c|}{$\begin{array}{c}\text { ECONOMICS DISCUSSION PAPERS } \\
2009\end{array}$} \\
\hline $\begin{array}{l}\text { DP } \\
\text { NUMBER }\end{array}$ & AUTHORS & TITLE \\
\hline 09.01 & Le, A.T. & $\begin{array}{l}\text { ENTRY INTO UNIVERSITY: ARE THE CHILDREN OF } \\
\text { IMMIGRANTS DISADVANTAGED? }\end{array}$ \\
\hline 09.02 & Wu, Y. & CHINA'S CAPITAL STOCK SERIES BY REGION AND SECTOR \\
\hline 09.03 & Chen, M.H. & $\begin{array}{l}\text { UNDERSTANDING WORLD COMMODITY PRICES RETURNS, } \\
\text { VOLATILITY AND DIVERSIFACATION }\end{array}$ \\
\hline 09.04 & Velagic, R. & UWA DISCUSSION PAPERS IN ECONOMICS: THE FIRST 650 \\
\hline 09.05 & McLure, M. & $\begin{array}{l}\text { ROYALTIES FOR REGIONS: ACCOUNTABILITY AND } \\
\text { SUSTAINABILITY }\end{array}$ \\
\hline 09.06 & Chen, A. and Groenewold, N. & $\begin{array}{l}\text { REDUCING REGIONAL DISPARITIES IN CHINA: AN } \\
\text { EVALUATION OF ALTERNATIVE POLICIES }\end{array}$ \\
\hline 09.07 & Groenewold, N. and Hagger, A. & $\begin{array}{l}\text { THE REGIONAL ECONOMIC EFFECTS OF IMMIGRATION: } \\
\text { SIMULATION RESULTS FROM A SMALL CGE MODEL. }\end{array}$ \\
\hline 09.08 & Clements, K. and Chen, D. & AFFLUENCE AND FOOD: SIMPLE WAY TO INFER INCOMES \\
\hline 09.09 & Clements, K. and Maesepp, M. & A SELF-REFLECTIVE INVERSE DEMAND SYSTEM \\
\hline 09.10 & Jones, C. & $\begin{array}{l}\text { MEASURING WESTERN AUSTRALIAN HOUSE PRICES: } \\
\text { METHODS AND IMPLICATIONS }\end{array}$ \\
\hline 09.11 & Siddique, M.A.B. & $\begin{array}{l}\text { WESTERN AUSTRALIA-JAPAN MINING CO-OPERATION: AN } \\
\text { HISTORICAL OVERVIEW }\end{array}$ \\
\hline 09.12 & Weber, E.J. & $\begin{array}{l}\text { PRE-INDUSTRIAL BIMETALLISM: THE INDEX COIN } \\
\text { HYPTHESIS }\end{array}$ \\
\hline 09.13 & McLure, M. & $\begin{array}{l}\text { PARETO AND PIGOU ON OPHELIMITY, UTILITY AND } \\
\text { WELFARE: IMPLICATIONS FOR PUBLIC FINANCE }\end{array}$ \\
\hline 09.14 & Weber, E.J. & $\begin{array}{l}\text { WILFRED EDWARD GRAHAM SALTER: THE MERITS OF A } \\
\text { CLASSICAL ECONOMIC EDUCATION }\end{array}$ \\
\hline 09.15 & Tyers, R. and Huang, L. & $\begin{array}{l}\text { COMBATING CHINA'S EXPORT CONTRACTION: FISCAL } \\
\text { EXPANSION OR ACCELERATED INDUSTRIAL REFORM }\end{array}$ \\
\hline 09.16 & $\begin{array}{l}\text { Zweifel, P., Plaff, D. and } \\
\text { Kühn, J. }\end{array}$ & $\begin{array}{l}\text { IS REGULATING THE SOLVENCY OF BANKS COUNTER- } \\
\text { PRODUCTIVE? }\end{array}$ \\
\hline 09.17 & Clements, K. & THE PHD CONFERENCE REACHES ADULTHOOD \\
\hline 09.18 & McLure, M. & $\begin{array}{l}\text { THIRTY YEARS OF ECONOMICS: UWA AND THE WA } \\
\text { BRANCH OF THE ECONOMIC SOCIETY FROM } 1963 \text { TO } 1992\end{array}$ \\
\hline 09.19 & Harris, R.G. and Robertson, P. & $\begin{array}{l}\text { TRADE, WAGES AND SKILL ACCUMULATION IN THE } \\
\text { EMERGING GIANTS }\end{array}$ \\
\hline 09.20 & $\begin{array}{l}\text { Peng, J., Cui, J., Qin, F. and } \\
\text { Groenewold, N. }\end{array}$ & STOCK PRICES AND THE MACRO ECONOMY IN CHINA \\
\hline 09.21 & Chen, A. and Groenewold, N. & $\begin{array}{l}\text { REGIONAL EQUALITY AND NATIONAL DEVELOPMENT IN } \\
\text { CHINA: IS THERE A TRADE-OFF? }\end{array}$ \\
\hline
\end{tabular}




\begin{tabular}{|c|c|c|}
\hline \multicolumn{3}{|c|}{$\begin{array}{l}\text { ECONOMICS DISCUSSION PAPERS } \\
2010\end{array}$} \\
\hline $\begin{array}{l}\text { DP } \\
\text { NUMBER }\end{array}$ & AUTHORS & TITLE \\
\hline 10.01 & Hendry, D.F. & $\begin{array}{l}\text { RESEARCH AND THE ACADEMIC: A TALE OF } \\
\text { TWO CULTURES }\end{array}$ \\
\hline 10.02 & McLure, M., Turkington, D. and Weber, E.J. & A CONVERSATION WITH ARNOLD ZELLNER \\
\hline 10.03 & $\begin{array}{l}\text { Butler, D.J., Burbank, V.K. and } \\
\text { Chisholm, J.S. }\end{array}$ & $\begin{array}{l}\text { THE FRAMES BEHIND THE GAMES: PLAYER'S } \\
\text { PERCEPTIONS OF PRISONER'S DILEMMA, } \\
\text { CHICKEN, DICTATOR, AND ULTIMATUM GAMES }\end{array}$ \\
\hline 10.04 & Harris, R.G., Robertson, P.E. and Xu, J.Y. & $\begin{array}{l}\text { THE INTERNATIONAL EFFECTS OF CHINA'S } \\
\text { GROWTH, TRADE AND EDUCATION BOOMS }\end{array}$ \\
\hline 10.05 & Clements, K.W., Mongey, S. and Si, J. & $\begin{array}{l}\text { THE DYNAMICS OF NEW RESOURCE PROJECTS } \\
\text { A PROGRESS REPORT }\end{array}$ \\
\hline 10.06 & Costello, G., Fraser, P., Groenewold, N. & $\begin{array}{l}\text { HOUSE PRICES, NON-FUNDAMENTAL } \\
\text { COMPONENTS AND INTERSTATE SPILLOVERS: } \\
\text { THE AUSTRALIAN EXPERIENCE }\end{array}$ \\
\hline 10.07 & Clements, $\mathrm{K}$. & $\begin{array}{l}\text { REPORT OF THE } 2009 \text { PHD CONFERENCE IN } \\
\text { ECONOMICS AND BUSINESS }\end{array}$ \\
\hline 10.08 & Robertson, P.E. & $\begin{array}{l}\text { INVESTMENT LED GROWTH IN INDIA: HINDU } \\
\text { FACT OR MYTHOLOGY? }\end{array}$ \\
\hline 10.09 & Fu, D., Wu, Y., Tang, Y. & $\begin{array}{l}\text { THE EFFECTS OF OWNERSHIP STRUCTURE AND } \\
\text { INDUSTRY CHARACTERISTICS ON EXPORT } \\
\text { PERFORMANCE }\end{array}$ \\
\hline 10.10 & Wu, Y. & $\begin{array}{l}\text { INNOVATION AND ECONOMIC GROWTH IN } \\
\text { CHINA }\end{array}$ \\
\hline 10.11 & Stephens, B.J. & $\begin{array}{l}\text { THE DETERMINANTS OF LABOUR FORCE } \\
\text { STATUS AMONG INDIGENOUS AUSTRALIANS }\end{array}$ \\
\hline 10.12 & Davies, M. & $\begin{array}{l}\text { FINANCING THE BURRA BURRA MINES, SOUTH } \\
\text { AUSTRALIA: LIQUIDITY PROBLEMS AND } \\
\text { RESOLUTIONS }\end{array}$ \\
\hline 10.13 & Tyers, R., Zhang, Y. & APPRECIATING THE RENMINBI \\
\hline 10.14 & Clements, K.W., Lan, Y., Seah, S.P. & $\begin{array}{l}\text { THE BIG MAC INDEX TWO DECADES ON AN } \\
\text { EVALUATION OF BURGERNOMICS }\end{array}$ \\
\hline 10.15 & Robertson, P.E., Xu, J.Y. & $\begin{array}{l}\text { IN CHINA'S WAKE: HAS ASIA GAINED FROM } \\
\text { CHINA'S GROWTH? }\end{array}$ \\
\hline 10.16 & Clements, K.W., Izan, H.Y. & $\begin{array}{l}\text { THE PAY PARITY MATRIX: A TOOL FOR } \\
\text { ANALYSING THE STRUCTURE OF PAY }\end{array}$ \\
\hline 10.17 & Gao, G. & WORLD FOOD DEMAND \\
\hline 10.18 & Wu, Y. & $\begin{array}{l}\text { INDIGENOUS INNOVATION IN CHINA: } \\
\text { IMPLICATIONS FOR SUSTAINABLE GROWTH }\end{array}$ \\
\hline 10.19 & Robertson, P.E. & DECIPHERING THE HINDU GROWTH EPIC \\
\hline
\end{tabular}

